\title{
INFLUENCE OF SOME DRYING METHODS ON VOLATILE OIL QUALITY OF PARSLEY (Petroselinum sativum Hoffm.) AND DILL (Anethum graveloens L.) PLANTS. Massoud,Hekmat. A.* ; R.M.M.Yousef** and Mona S. Megahed ${ }^{* *}$ \\ * Vegt. and Flor. Dept., Fac. Agric., Mansoura Univ. \\ ** Medicinal and Aromatic Plants Dept., Hort. Res. Institute, Agric. Res. Center.
}

\begin{abstract}
Drying process may contribute to regular supply and facilitate the marketing of plants, because it facilitates the transport and storage. Two of the most commonly used herbs and cultivated throughout the Mediterranean region are parsley (Petroselinum sativum Hoffm.) and dill (Anethum graveloens L.) plants belongs to Fam. "Apiaceae" (Umbelliferae) were used in the present work.

The present study was carried out at the Experiment Farm of Horticulture Research Station in EL-Kassasen, Ismailia Governorate, Egypt, in two successive winter seasons of $2006 / 2007$ and $2007 / 2008$ to investigate the influence of some drying methods (shade at $20 \pm 2{ }^{\circ} \mathrm{C}$, oven at $45^{\circ} \mathrm{C}$, sun at $30 \pm 3^{\circ} \mathrm{C}$ and greenhouse at $\left.35 \pm 5^{\circ} \mathrm{C}\right)$, on the plant dry weight ( $\left.\mathrm{g} / 100 \mathrm{~g} \mathrm{FW}\right)$, moisture content (\%), the volatile oil quality and quantities of parsley and dill plants.

The physical and chemical properties of the volatile oil of the two fresh plants viz., specific gravity, refractive index and optical rotation were determined and are included in this study.

The results showed that the shade drying method was the best treatment to produce the highest volatile oils percentage of both plants, while oven drying gave the highest percentage of volatile oils components. On the other hand, sun drying method was the lowest one since it caused a decrease in the plant quality.

The G.L.C. of the parsley volatile oil revealed a total of 10 compounds were $\alpha$ - and $\beta$ - pinene, sabinene, limonene, $\alpha$ - and $\beta$ - phellandren, myrcene, $p$-cymene, myresticine and apiol. The total identified compounds constituent 74.6, 79.5, 91.1, 86.6 and $72.1 \%$ in the oil of the control, shade, oven, sun and greenhouse drying methods, respectively. While, the G.L.C. of the dill volatile oil revealed a total of 11 compounds were $\alpha$ - and $\beta$ - pinene, myrcene, limonene, $p$-cymen, $\alpha$ - and $\beta$ phellandren, 3,9- epoxy-p-menthlen, trans - dihydrocarvon, cis- dihydrocarvon and carvon. The total identified compounds constituent 100, 97.7, 98.2, 92.2 and $89.4 \%$ in the oil of the control, shade, oven, sun and greenhouse drying methods, respectively. The method of drying affected the proportion of the oil components in the two plants.

The volatile oil \% of the total main components ( $\alpha$ - and $\beta$-pinene, myresticine and apiol) was $34.5,46.7,59.4,45.8$ and $36.8 \%$ of parsley plants in the oil of the control, shade, oven, sun and greenhouse drying methods, respectively. While, the volatile oil \% of the total main components ( $\alpha$ - phellendren and limonene) was 71.2, $71.5,78.6,57.9$ and $64.8 \%$ of dill plants, in the oil of the control, shade, oven, sun and greenhouse drying methods, respectively.

The method of drying included oven dried at $45{ }^{\circ} \mathrm{C}$ for $6 \mathrm{hr}$. was the best procedure to produce parsley and dill dried materials if compared with the other tested methods, since it kept the leaf volatile oils with characterised features increasing yield quantity and quality.
\end{abstract}




\section{INTRODUCTION}

Medicinal and Aromatic plants (MAP) are considered one of the important products in Egypt. Moreover, the exportation from MAP is less than the Egyptian sharing in the international market. The World Health Organization estimates that $80 \%$ of the world's population uses medicinal plants in some way, (Lemos et al., 2008). The use of herbs in food industry has increased significantly because of their antioxidant action on lipid degradation, besides their traditional role in food aroma and used in several industrial usages and applications such as pharmaceutical preparations, foods, and cosmetic, (Venskutonis, 1997).

Parsley (Petroselinum sativum Hoffm.) is one of the most commonly used herbs, originated from northern and central Europe and western Asia. The plant is an annual or biennial herb, cultivated throughout the Mediterranean region. The fresh herb is widely used in cooking. Parsley leaves, seed, and roots treat urinary tract infections and help eliminate kidney stones. The plant was used against the effects of malaria. The oil is obtained by steam distillation from the ripe seeds leaf or herb, which gives an average yield of $0.1 \%$ from leaves and $6 \%$ from the fruits. It is stimulates appetite and reduces fevers, as well as, increases blood flow to digestive organs. The high content of vitamin A \& C is not only useful in its own right, but also assists the absorption of the valuable quantity of iron. The volatile components in leaf oil are $\alpha$ - and $\beta$ - pinene, myrcene, $\beta$-phellandren and apiol that gave a parsley odor, (Keville, 1999 and Panda 2000).

Dill (Anethum graveloens L.) is an annual herb native to southwestern Asian and the Mediterranean and naturalized extensively throughout Europe and North America. The fresh dill herbs are used as a seasoning for soups, sauces, and particularly pickles and an important source of vitamins. The herb is aromatic, but most of the volatile oil is contained in the seed (fruit). The herb oil or weed oil is obtained from the herb including the immature fruit. The typical odor and flavor of the herb oil are chiefly due to its content of phellanderen, the seed oil having a caraway-like odour and flavour. The seed oil has high carvon content (40 to $60 \%$ ) as compared to dill weed oil, which their character increases with diminished carvon contents. The dill herb oil is mainly used for flavouring and seasoning purposes in the food industry. It is used also in pharmaceutical and other preparation to relieve stomach pain in babies, helpful for digestive problems, sedative, antioxidant, antispasmodic, antiseptic and diuretic. The oil kills bacteria and relieves flatulence, (Keville, 1999 and Panda, 2000).

Drying process of MAP is very important to meet the requirements for quality of plants and make them available for foreign and local markets. For this reason, adequate dryer are needed, using temperature values for drying air that provides a rapid reduction in the water content without affecting the quality of medicinal plants active principles, (Bohm et al., 2006). The duration of drying process varies from a few hours to many weeks. For dry commodities, the method of drying, i.e. air drying in sun or shade depending largely on the weather. Artificial drying is more rapid and helps flowers and 
leaves to retain their color and aroma. A number of attempts have been made to establish novel drying techniques for improving not only product quality, but also economic efficiency, (Venkatachalapathy and Raghavan, 1999). Guenther (1961) stated that the direct exposure of plants to the sun tended to break the stalks and made the leaves brittle. Balbaa et al. (1974) found that shade drying increased glycosidal content in Digitalis lanatan leaves, and they added that shade drying had provided favorable and satisfactory method for quality as well as a practical and economic one. Skrubis (1982) found that air drying of laurel leaves at $40,50,60$ or $70^{\circ} \mathrm{C}$ did not affected the oil composition. Refaat (1988) studied the effect of drying method on sweet marjoram herb, and concluded that the changes in oil constituents were the least when the herb was dried in the shade. Shalaby et al. (1988) found that oven drying at $60{ }^{\circ} \mathrm{C}$ reduces the essential oil content of the mint plants, whereas air drying at $27-30{ }^{\circ} \mathrm{C}$ had no effect on essential oil content. Diaz- Maroto et al. (2002) mentioned that the air drying at ambient temperature resulted few losses in volatile compounds of parsley (Petroselinum crispum) compared with the fresh herb, whereas oven drying at $45^{\circ} \mathrm{C}$ caused a decrease in the concentrations of the majority of the volatile components. Omidbaigi et al., (2004) reported that the oil content of the shade dried flowers of Roman chamomile was the largest compared to sun- drying and oven-drying at $40^{\circ} \mathrm{C}$. Kassem et al. (2006) reported that the drying methods decreased essential oil content in lemongrass, oregano, spearmint and peppermint plants and the solar drying method was better than the natural drying (sun drying) and artificial drying (in oven at $45^{\circ} \mathrm{C}$ ). On contrary, Sefidkon et al. (2006) mentioned that the drying method had no significant effect on oil composition of Saturia hortensis.

Volatile aroma compounds are the most sensitive components in the process of food drying, the effect of drying method on the volatile oil content and composition were studied by many investigators. The change in the concentrations of the volatile compounds during drying process may have an influence on the content of aroma compounds, (Venskutonis, 1997). Only few investigations are known about the effect of drying upon the quality of aromatic herbs. Due to the above mentioned information, this work aimed to attain the best of drying methods on the quality and quantities of parsley and dill volatile oils.

\section{MATERIALS AND METHODS}

The trials were aimed at finding the suitable drying methods to obtain a desirable volatile oil quality of parsley (Petroselinum sativum Hoffm.) and dill (Anethum graveloens L.) plants belongs to Fam. "Apiaceae" (Umbelliferae) were used in the present work.

The study was carried out at the Experiment Farm of Horticulture Research Station in EL-Kassasen, Ismailia Governorate, Egypt, during two successive winter seasons of 2006/2007 and 2007/2008. 
In both winter seasons, the plants were harvested in February by cutting the aerial parts of each plant $(20 \mathrm{~cm})$ above the soil surface at commencement of flowering in the morning.

Drying methods:

Samples of parsley and dill were divided into four set, $10 \mathrm{~kg}$ of the fresh herb was taken to each one way of drying methods and put in the groups each $100 \mathrm{~g}$ form the following different drying procedures:

1. Shade drying: The fresh plants were put in open ventilated area at $20 \pm 2$ ${ }^{\circ} \mathrm{C}$ in one layer paper for 15 days until the complete drying.

2. Oven drying: The fresh plants were put in one layer paper in oven at 45 ${ }^{\circ} \mathrm{C}$ for 6 hours until the complete drying.

3. Sun drying: The fresh plants were put in one layer paper at $30 \pm 3^{\circ} \mathrm{C}$ for 7 10 days until the complete drying.

4. Greenhouse drying: The fresh plants were put in one layer paper at $35 \pm$ $5^{\circ} \mathrm{C}$ for 5 days until the complete drying.

The following data were recorded:

1. Herb dry weight (g / 100g FW): Plant samples (100g) were chosen randomly from each treatment and dried at shade, oven, sun and greenhouse drying methods. The dry weight were recorded when its weight remained constant.

2. Moisture percentage (\%): Plants were chosen randomly from each treatment and their moisture \% was calculated by drying $50 \mathrm{~g}$ of the samples at $70^{\circ} \mathrm{C}$ in oven with air circulation until a constant weight.

3. Volatile oil determination: Five samples each $(100 \mathrm{~g})$ using from the fresh and dry herb each replicate in both winter seasons were determined by hydro-distillation in Clevenger apparatus according to methods described by the Egyptian Pharmacopoeia (1984).

4. Physical and chemical properties of oil: The specific gravity, the refractive index and the optical rotation of the volatile oil were determined according to the methods described by Guenther (1949). These measurements were analyzed at the laboratory of the chemistry Dept., Fac Agric., Mansoura Univ.

5. Identification of the volatile oil composition (\%): The relative content of the major components in the oil was determined from the second season plants by using Gas Liquid Chromatography Technique (G.L.C.), which carried out at the Laboratory of Medicinal and Aromatic Plants Section, Agric. Res. Center. The relative retention time (RT) of each peak was compared with the authentic sample to identify the unknown samples. The quantitative estimation for each component was based on the peak area measurement by triangulation according to Guenther and Joseph (1978).

\section{Statistical analysis}

The experimental design was simple experiment with 4 replicates used in both seasons and both plants according to Steel and Torrie (1980). Data were subjected to the statistical analysis and the differences between the means of the treatments were compared using the least significant differences (L.S.D) at 5 \% level as mentioned by Gomez and Gomez (1984). 


\section{RESULTS AND DISCUSSION}

\section{I) Effect of drying methods on herb dry weight (g / 100g FW), moisture} (\%) and volatile oil (\%).

1. On parsley plant:

Data presented in Figure (1), indicate that, the dry weight was affected by the different drying methods (shade, oven, sun and greenhouse), the highest values were $(20.29$ and $20.31 \mathrm{~g} / 100 \mathrm{~g} \mathrm{FW})$ from the shade drying at $20 \pm 2{ }^{\circ} \mathrm{C}$, while the lowest values were (17.22 and $\left.17.61 \mathrm{~g} / 100 \mathrm{~g} \mathrm{FW}\right)$ from oven drying at $45^{\circ} \mathrm{C}$ in both winter seasons, respectively. Moisture content $(\%)$ is considered to be one of the most important factors influencing the quality attributes of dried herbs. The highest moisture (\%) per $100 \mathrm{~g}$ fresh herb gave from oven drying (82.78 and $82.39 \%$ ), while the lowest values gave from shade drying (79.71 and $79.69 \%)$ in two winter seasons, respectively. In addition to the volatile oil (\%), the data in Figure (1) showed that the highest oil percentage was (0.10 and $0.13 \%)$ and $(0.09$ and $0.11 \%)$ from the shade and oven drying, respectively in the first and second seasons. While, the lowest oil percentage was $(0.06$ and $0.07 \%)$ and $(0.07$ and $0.08 \%)$ from the sun and greenhouse drying compared to the fresh plants (control) was $(0.04$ and $0.05 \%)$ in the first and second winter seasons, respectively.

\section{On dill plant:}

Data presented in Figure (1), indicate that, the dry weight was affected by the different drying methods (shade, oven, sun and greenhouse), the highest values were (18.33 and $18.81 \mathrm{~g} / 100 \mathrm{~g} \mathrm{FW})$ from the shade drying at $20 \pm 2{ }^{\circ} \mathrm{C}$, while the lowest values were (15.29 and $\left.16.07 \mathrm{~g} / 100 \mathrm{~g} \mathrm{FW}\right)$ from oven drying at $45{ }^{\circ} \mathrm{C}$ in both winter seasons, respectively. The highest moisture (\%) per $100 \mathrm{~g}$ fresh herb were (84.71 and $83.93 \%)$, from oven drying at $45{ }^{\circ} \mathrm{C}$, while the lowest values were (81.67 and $\left.81.19 \%\right)$, from shade drying in the two winter seasons, respectively. In the same Fig. the highest oil percentages were (1.80 and $1.32 \%)$, (1.41 and $1.21 \%)$ and (1.35 and $1.17 \%$ ) from the shade, oven and greenhouse drying, respectively, while the lowest was $(0.57$ and $0.56 \%)$ from the sun drying compared to the fresh plants (control) were $(0.19$ and 0.18$)$ in the both winter seasons, respectively. The results are harmonious with a previous report from Karawya et al. (1977) found that drying mint plants in the sun had decreased the essential oil content by $75 \%$. Refaat (1992) announced that laurel volatile oil percentage obtained from oven dried leaves at $40{ }^{\circ} \mathrm{C}$ was higher than that from shade and sun dried ones by 27.21 and $23.13 \%$ respectively, and concluded that more rapid drying produce more oil percentage. Chang et al. (1996) mentioned that the yield and chemical composition of essential oils from Grenadian nutmegs was decreased with increasing drying temperatures to $45^{\circ} \mathrm{C}$, and this was associated with decreases in monoterpene hydrocarbon content. They announced Maximum essential oil yields on a dry weight basis were obtained for nutmegs dried at $21-23^{\circ} \mathrm{C}$. Muller et al. (1996) reported that medicinal plants are usually harvested at $80 \%$ moisture 
Massoud,Hekmat. A. et al.
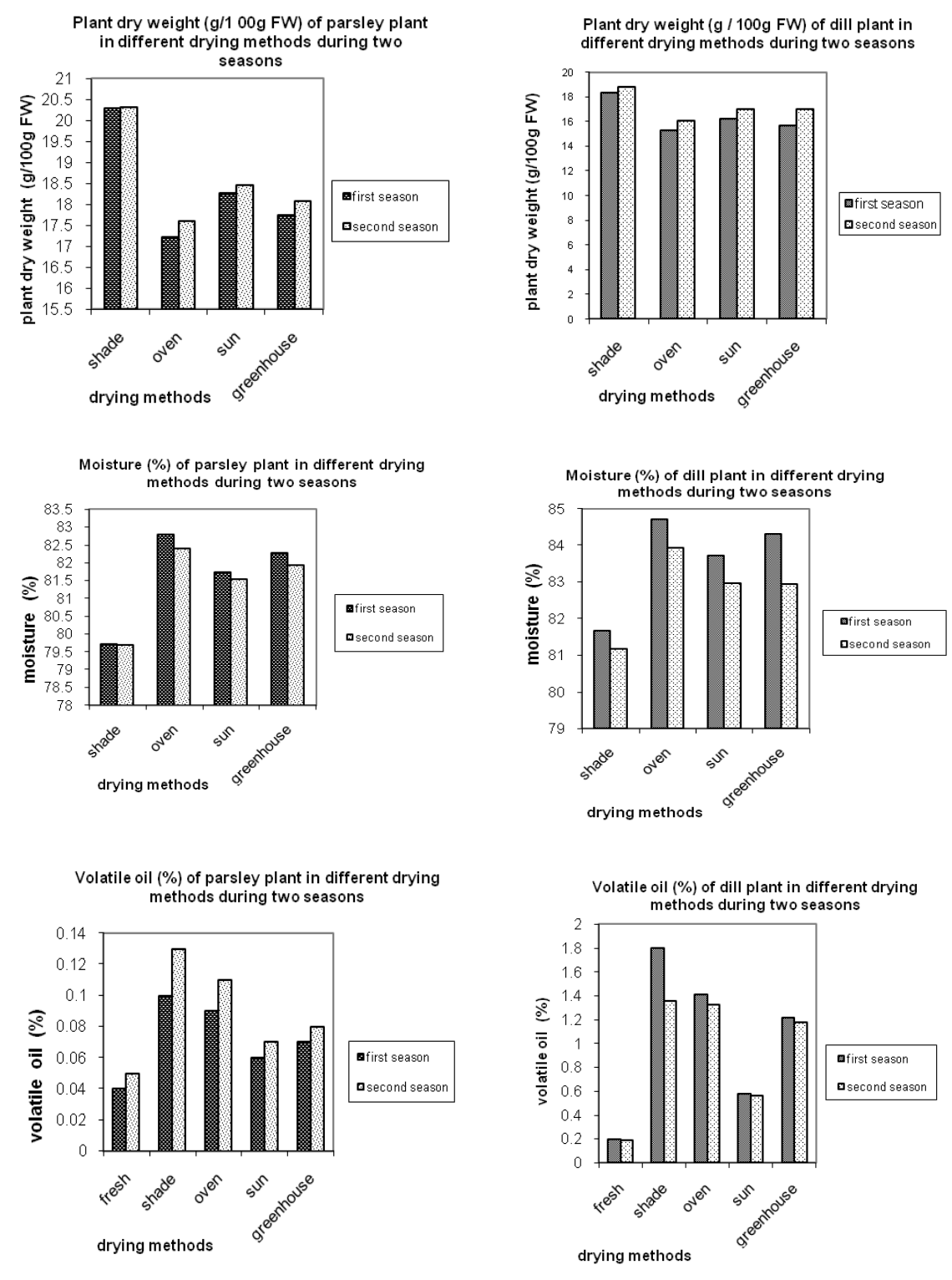

Parsley

Dill

Figure (1): Effect of drying methods on herb dry weight (g / $100 \mathrm{~g} \mathrm{FW}$ ), moisture (\%) and volatile oil (\%) of parsley and dill plants in two winter seasons. 
content and stored at $11 \%$. Refaat and Wahba (1998) stated that shade drying of lavender herb showed more conspicuous effect on the volatile oil content, since the decrement in oil percentage of sun and oven dried plants reached 12.07 and $30 \%$ respectively. Abdalla et al. (2002) noticed that, the highest percentage of essential oil of lemongrass (Cymbopogon citratus) was obtained from drying plant in shade, while the lowest one was obtained from drying in sun. Diaz-Maroto et al. (2002) recorded that oven drying at $45^{\circ} \mathrm{C}$ and air - drying at ambient temperature produced quite similar results and caused hardly any loss in volatile oil of bay leaf (Laurus nobilis L.) as compared to the fresh herb. Omidbaigi et al. (2004) reported that the flowers of Roman chamomile dried by three different drying methods of sun drying, shade drying and oven drying at $45{ }^{\circ} \mathrm{C}$ and the oil content of the shade dried flowers was the largest compared to sun drying and oven drying at $45^{\circ} \mathrm{C}$. According to this growing demand for medicinal species, artificial drying has been one of the most important processes in agricultural products, aiming to meet the phototherapy product needs of the pharmaceutical industry, which does not have structure to use fresh plants in the quantities required for industrial production. It is clear that artificial drying is more rapid and helps flowers and leaves to retain their color and aroma.

\section{II) Physical and chemical properties of parsley and dill volatile oil:}

The most important physical and chemical properties of the volatile oil of parsley and dill plants viz., specific gravity, refractive index and optical rotation were determined and the results are shown in Table (1). Most of the values were to be within the range mentioned by Guenther (1961). The physical and chemical properties of parsley and dill herb oil are thus greatly influence by the maturity of the plant material.

Table (1): Physical and chemical properties of the parsley and dill volatile oil.

\begin{tabular}{|c|c|c|c|}
\hline Essential oil & $\begin{array}{c}\text { Specific gravity } \\
\text { at } 25^{\circ} \mathbf{C}\end{array}$ & $\begin{array}{c}\text { Refractive index } \\
\text { at } 20^{\circ} \mathbf{C}\end{array}$ & $\begin{array}{c}\text { Optical rotation } \\
\text { at } 25^{\circ} \mathbf{C}\end{array}$ \\
\hline Local parsley & 0.902 & 1.526 & +10 \\
\hline Local dill & 0.884 & 1.4850 & +95 \\
\hline
\end{tabular}

\section{III) Effect of drying methods on the volatile oil components (\%): \\ 1. On parsley plant:}

The results of G.L.C. analysis are shown in Table (2) and Figure (2). Data showed the effect of drying methods (shade at $20 \pm 2{ }^{\circ} \mathrm{C}$, oven at $45^{\circ} \mathrm{C}$, sun at $30 \pm 3{ }^{\circ} \mathrm{C}$ and greenhouse at $35 \pm 5^{\circ} \mathrm{C}$ ) on the volatile oil constituents of parsley plants. The G.L.C. of the oil revealed a total of 10 components were $\alpha$ - and $\beta$ - pinene, sabinene, myrcene, $\alpha$ - and $\beta$ - phellandren, limonene, p- cymene, myresticine and apiol. The identified compounds constituted 74.6, $79.5,91.1,86.6$ and $72.1 \%$ in the oil of fresh plants, shade, oven, sun and greenhouse drying methods, respectively in parsley plant. 
Massoud,Hekmat. A. et al.

Table (2): Effect of drying methods on the volatile oil components (\%) of parsley plant.

\begin{tabular}{|c|c|c|c|c|c|}
\hline \begin{tabular}{|l|} 
Essential oil \\
components (\%)
\end{tabular} & $\begin{array}{l}\text { Fresh } \\
\text { control }\end{array}$ & $\begin{array}{l}\text { Shade at } \\
20 \pm 2{ }^{\circ} \mathrm{C}\end{array}$ & $\begin{array}{c}\text { Oven at } \\
45^{\circ} \mathrm{C} \text {, }\end{array}$ & $\begin{array}{c}\text { Sun at } \\
30 \pm 3^{\circ} \mathrm{C}\end{array}$ & $\begin{array}{l}\text { Greenhouse } \\
\text { at } 35 \pm 5^{\circ} \mathrm{C}\end{array}$ \\
\hline a-pinee & 9.85 & 7.31 & 15.95 & 5.19 & 11.54 \\
\hline$\beta$-pinene & 5.57 & 19.57 & 12.10 & 20.17 & 12.40 \\
\hline sabinene & 2.39 & 1.80 & 1.72 & 1.47 & 1.45 \\
\hline mrcene & 4.92 & 4.48 & 1.44 & 7.37 & 5.76 \\
\hline$\alpha$-phyllendren & 9.28 & 7.45 & 8.68 & 11.08 & 10.29 \\
\hline limonene & 5.76 & 5.73 & 7.34 & 5.78 & 5.34 \\
\hline$\beta$ - phyllendren & 10.04 & 9.45 & 6.04 & 11.35 & 9.33 \\
\hline p- cymene & 7.69 & 3.89 & 6.41 & 3.69 & 3.17 \\
\hline myresticine & 9.61 & 8.40 & 15.89 & 6.42 & 5.31 \\
\hline apiol & 9.51 & 11.44 & 15.48 & 14.06 & 7.51 \\
\hline $\begin{array}{l}\text { Known } \\
\end{array}$ & 74.62 & 79.52 & 91.05 & 86.58 & 72.10 \\
\hline
\end{tabular}
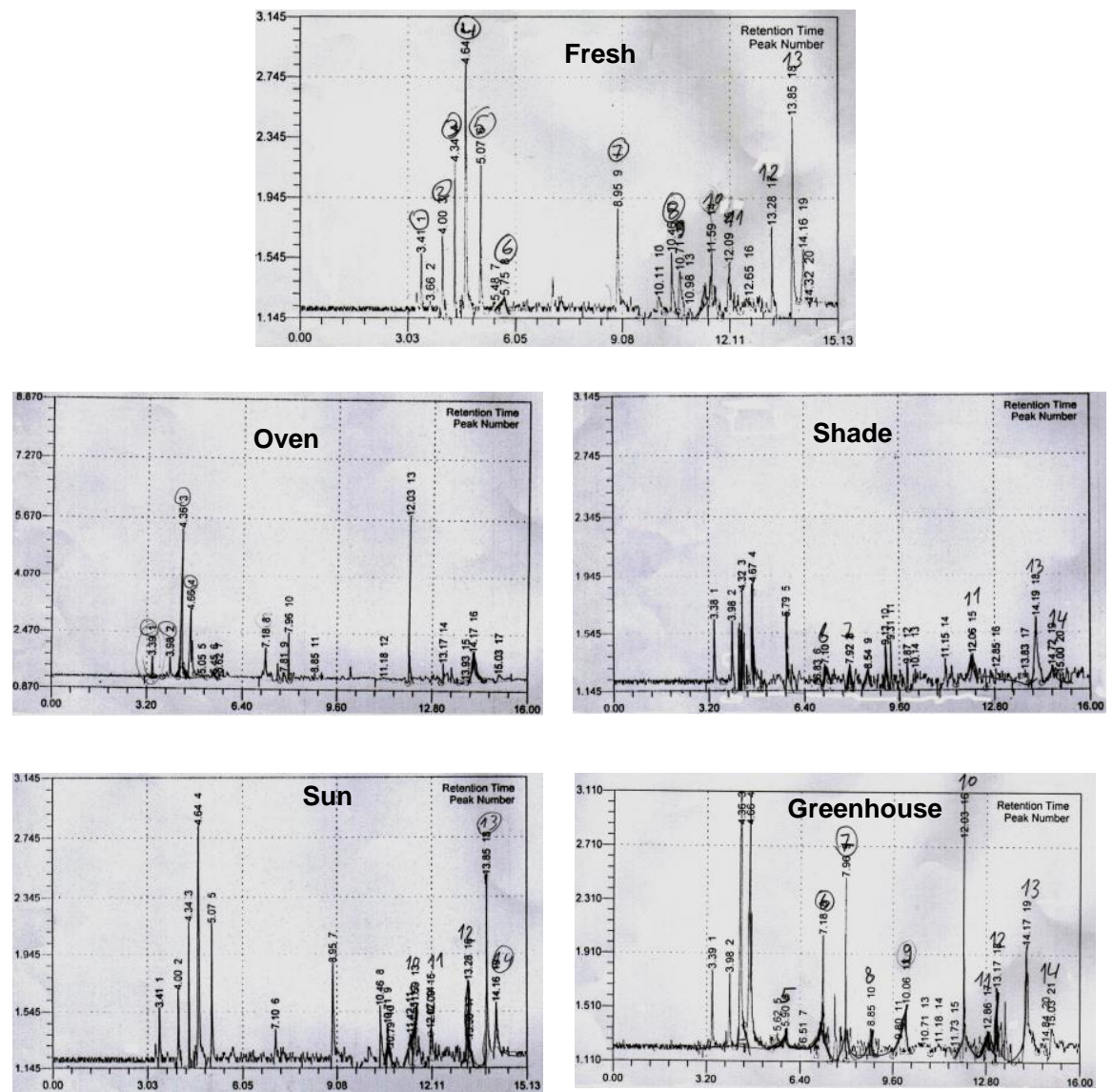

Figure (2): Effect of drying methods on the volatile oil components (\%) of parsley plant. 
The total main components ( $\alpha$ - and $\beta$ - pinene, myresticine and apiol) were $34.5,46.7,59.4,45.8$ and $36.8 \%$ of volatile oil. The highest main components of the volatile oil were myresticine $(15.89 \%)$ and apiol $(15.48 \%)$ gave from oven drying at $45{ }^{\circ} \mathrm{C}$, while the lowest were myresticine $(5.31 \%)$ and apiol $(7.51 \%)$ from greenhouse drying. The highest main component $\alpha$ - pinene was (15.95 and $11.54 \%)$ from drying at oven and greenhouse, while the lowest was (7.31 and $5.19 \%$ ) from drying at shade and sun, respectively. The highest main component $\beta$ - pinene (20.17 and $19.57 \%)$ gave from drying at sun and shade, while the lowest was (12.4 and $12.1 \%$ ) from drying at greenhouse and sun, respectively. Results revealed that the drying method had a significant effect on the proportion of the total main components in essential oil of parsley plant.

\section{On dill plants:}

The results of G.L.C. analysis are shown in Table (3) and Figure (3) Data showed the effect of drying methods (shade at $20 \pm 2{ }^{\circ} \mathrm{C}$, oven at $45^{\circ} \mathrm{C}$, sun at $30 \pm 3{ }^{\circ} \mathrm{C}$ and greenhouse at $35 \pm 5^{\circ} \mathrm{C}$ ) on the volatile oil constituents of dill plants. The G.L.C. revealed a total of 11 compounds were $\alpha$ - and $\beta$ - pinene, myrcene, limonene, $\alpha$ - and $\beta$ - phellandren, $p$ - cymene, 3.9- epoxy$\mathrm{p}$ - menthlen, trans - dihydrocarvon, cis- dihydrocarvon and carvon. The identified compounds constituted 100, 97.7, 98.2, 92.2 and $89.4 \%$ in the oil of fresh plants, shade, oven, sun and greenhouse drying methods, respectively. The highest percentage of the total main components $\alpha$ - phyllendren and limonene was $(78.57 \%)$ from oven drying at $45^{\circ} \mathrm{C}$, while the lowest was $(57.92 \%)$ from sun drying at $25 \pm 3^{\circ} \mathrm{C}$. In the same Table the shad and oven drying methods had a similar percentage of $\beta$ - phyllendren. The highest percentage $(10.81 \%)$ gave from sun drying while, the lowest $(6.59 \%)$ from greenhouse drying method. Results revealed that the drying method had a significant effect on the proportion of the total main components in essential oil of dill plant.

Table (3): Effect of drying methods on the volatile oil components (\%) of dill plant.

\begin{tabular}{|c|c|c|c|c|c|}
\hline $\begin{array}{c}\text { Essential oil } \\
\text { components (\%) }\end{array}$ & $\begin{array}{l}\text { Fresh } \\
\text { control }\end{array}$ & $\begin{array}{l}\text { Shade at } \\
20 \pm 3^{\circ} \mathrm{C}\end{array}$ & $\begin{array}{l}\text { Oven } \\
\text { at } 45^{\circ} \mathrm{C}\end{array}$ & $\begin{array}{c}\text { Sun at } \\
30 \pm 3^{\circ} \mathrm{C}\end{array}$ & $\begin{array}{l}\text { Greenhouse } \\
\text { at } 35 \pm 5^{\circ} \mathrm{C}\end{array}$ \\
\hline$\alpha$ - pinene & 1.27 & 0.76 & 0.33 & 1.71 & - \\
\hline$\beta$ - pinene & 1.46 & 3.30 & 1.72 & 1.73 & 2.66 \\
\hline myrcene & 1.41 & 1.48 & 1.07 & 2.06 & 0.08 \\
\hline$\alpha-$ phyllendren & 42.81 & 44.81 & 45.99 & 35.21 & 38.18 \\
\hline limonene & 28.40 & 26.64 & 32.58 & 22.71 & 26.60 \\
\hline$\beta$ - phyllendren & 13.55 & 8.90 & 8.97 & 10.81 & 6.59 \\
\hline p- cymene & 0.33 & 3.00 & 0.96 & 4.05 & 3.46 \\
\hline 3.9-epoxy-p-menthlen & 1.27 & 1.22 & 1.44 & 0.65 & 0.18 \\
\hline trans- dihydrocarvon & 2.17 & 1.94 & 0.26 & 0.99 & 0.40 \\
\hline cis- dihydrocarvon & 1.89 & 2.00 & 1.01 & 2.40 & 1.25 \\
\hline carvon & 5.44 & 3.65 & 3.88 & 6.01 & 10.00 \\
\hline known & 100 & 97.7 & 98.2 & 92.2 & 89.4 \\
\hline
\end{tabular}



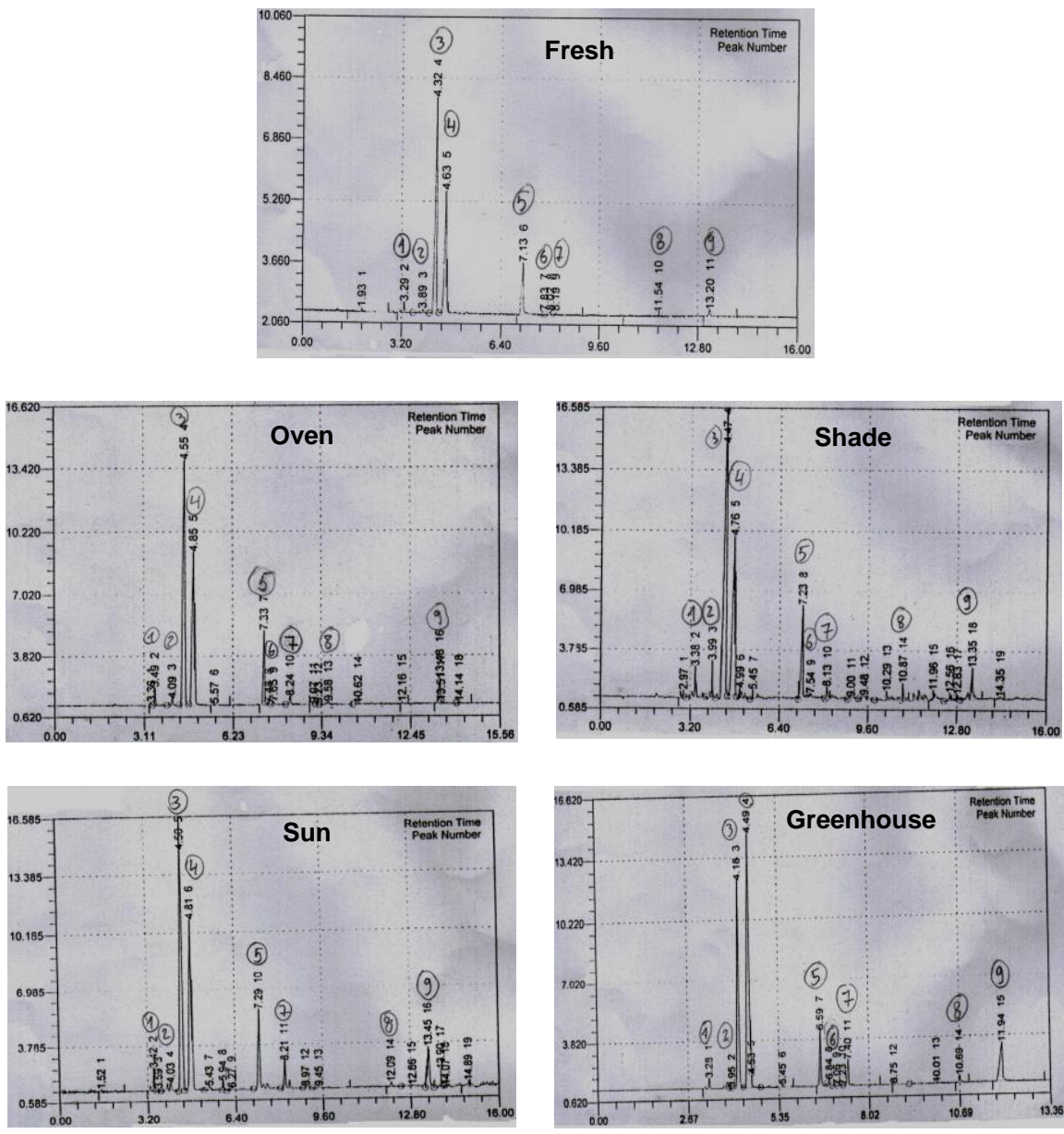

Figure (3): Effect of drying methods on the volatile oil components (\%) of dill plant.

The same results were noticed from Sefidkon et al. (2006) showed that the different drying methods had a significant effect on the percentage of main components of Saturia hortensis. Asekun et al. (2007) showed that the various methods of drying affected on the content and chemical quality of the essential oil of Mentha longifolia.

\section{Conclusion:}

The method of drying included oven dried at $45^{\circ} \mathrm{C}$ for $6 \mathrm{hr}$. was the best procedure to produce parsley and dill dried materials if compared with the other tested methods, since it kept the leaf volatile oils with characterised features increasing yield quantity and quality. 


\section{REFERENCES}

Abdalla, M. Y. A.; H. Y.; Massoud and H. A. Ali (2002). Effect of different drying and storage methods on the quality of lemongrass oil (Cymbopogon citratus). J. Agric. Sci. Mansoura Univ. 27(1): 459-468.

Asekun, O. T.; D. S. Grierson and A. J. Afolayan (2007). Effect of drying methods on the quality and quantity of essential oil of Mentha longigolia L. subsp. Capensis. Food Chemistry. 101 (3): 995-998.

Balbaa, S. I.; S. H. Hilal and M. Y. Haggag (1974). Effect of the use of different methods of drying Digitalis lanata leaves on their quality and glycosidal content. Planta medica, 261(1): 20-25.

Bohm, V.; S. Kuhnert, H. Rohm and G. Scholze (2006). Improving the Nutritional Quality of Microwave-vacuum dried strawberries: A preliminary study. Food Sci. Tech. Int. 12(1):67-75.

Chang Yen, I.; R. Sookram and D. Mc-Gaw (1996). Yield and chemical composition of essential oils of Grenadian nutmegs. Tropical Agric. 73(4): 301.

Diaz-Maroto, M. C.; M. S. Perez-Coello and M. D. Cabezudo (2002). Effect of drying method on the volatiles in bay leaf (Laurus nobilis L.). J. Agricultural and Food Chemistry. 50(16): 4520-4524.

Diaz-Maroto, M.C.; M.S. Perez-Coello and M.D. Cabezudo (2002). Effect of different drying methods on the volatile components of parsley (Petroselinum crispum L.). European Food Research and Technology. 215(3): 227-230.

Egyptian Pharmacopoeia (1984). Egyptian Pharmacopoeia, General Organization for Governmental. Printing Office, Ministry of Health, Cairo, Egypt, 31-33.

Gomez, K. A. and A. A. Gomez (1984). Statistical Procedures Res. $2^{\text {nd }}$ Ed. John Wiley and Sons, Inc., New York, USA.

Guenther, E. (1949): The Essential Oil, Vol. 1. History- origin in plants and production analysis. Dr.Van.Nostrand Company., Inc. N Y, USA.

Guenther, E. (1961). The Essential Oils. Vol. IV. Individual essential oils of the plant family Umbelliferae. $4^{\text {th }} \mathrm{Ed}$. Dr. Van Nostrand Company, Inc. pp. 618-663.

Guenther, Z. and S. Joseph (1978). Handbook Series in Chromatography CRC press, USA.

Karawya, M.S.; M.S. Hifnawy and S. El-Hawary (1977). Effect of nitrogen fertilizer time of cutting and drying of Mentha piperita L. and Mentha spicata L. Egypt J. Pharm. Sci. 18(4): 405-22.

Kassem, A. M.; I. E. EL-BATAWI and M. M. A. Sidky (2006). Effect of solar energy and other drying methods on quality of some medicinal plants. The 14 ${ }^{\text {th }}$ Annual Conference of Society of Agr. Eng., Nov. 22: 766-782.

Keville, K. (1999). Herbs"An Illustrated Encyclopedia" Michael Friedman Publishing Group Inc. p. 167-168. 
Lemos, D.; R. Rocha, E. Melo, E. Visser and A. Pinheiro (2008). Influence of drying air temperature on the essential oil content from Melaleuca alternifolia Cheel. CIGR- International Conference of Agricultural Engineering, XXXVII Congresso Brasileiro de Engenharia AgricolaCONBEA, 31 Aug. to 4 Sept.

Muller, J.; T. Conrad; B. Thome and W. Muhlbauer (1996). Drying of medicinal plants in a plastics solar drier. Plasticulture. 112: 33-41

Omidbaigi, R.; F. Sefidkon and F. Kazemi (2004). Influence of drying methods on essential oil content and composition of Roman chamomile. Flavour and Fragrance Journal. 19: 196-198.

Panda, H. (2000). Essential Oils Hand Book. Published by National Insitute of Industrial Research, Delhi. P.174 -175 and 188-190.

Refaat, A. M. (1988). Effect of Fertilization levels, method of drying and periods of storage on the sweet marjoram herb yield and its active ingredients. Ph.D., Thesis, Fac. Agric. Ain Shams Univ.

Refaat, A.M. (1992). Post harvest study on laurel leaves. Bull. Fac. Agric., Cairo Univ. 43(3): 965-976.

Refaat, A.M. and H.E. Wahba (1998). Some factors affecting lavender plant productivity. Annals Agric. Sci. Ain Shams Univ.43(1): 273-285.

Sefidkon, F.; K. Abbasi and Gh. B. Khaniki (2006). Influence of drying and extraction methods on yields and chemical composition of the essential oil of Saturia hortensis. Food Chemistry. 99: 19-23.

Shalaby, A. S.; A.M. El-Gamasy; S. El-Gengaihi and M. Khattab (1988). Post harvest studies on herb and oil of Mentha arvensis L. Egyptian $\mathrm{J}$. Horticulture, 15(2): 213-224.

Skrubis, B.G. (1982). The drying of laurel leaves. Perfumer and Flavours, 7(50): 37- 40.

Steel, R.R. and J.H. Torrie (1980). Principles and Procedures of Statistics. MC. Graw-Hill International Book Company, $3^{\text {rd }}$ Ed. London, pp. 633.

Venkatachalapathy, K. and G.Raghavanc (1999). Shrinkage of strawberries during microwave drying. Drying Technology. 17: 2309 -2321.

Venskutonis, P. (1997). Effect of drying on the volatile constituents of thyme (Thymus vulgaris L.) and sage (Salvia officinalis L.). Food Chemistry, 59(2): 219-227. 


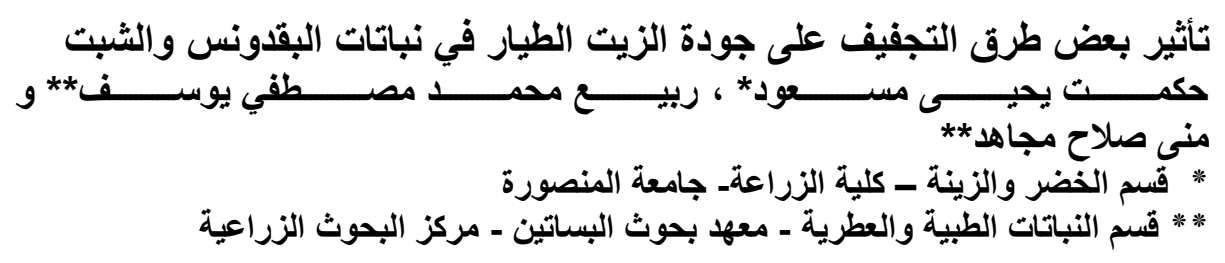

يعتبر تجفيف النباتات الطبية والعطرية والأعثاب من الأهمية لمواجهة الحاجة الملحة لتحسين جودة النباتات وجطلها متاحة للسوق البتات الطبية والعالمي.

أجريت هذه الدراسة في المزرعة البحثية لمحطة بحوث البساتين بالقصاصين بمحافظة الاسماعيلية

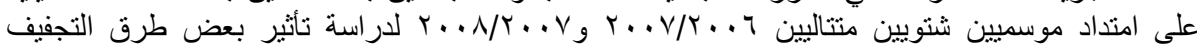

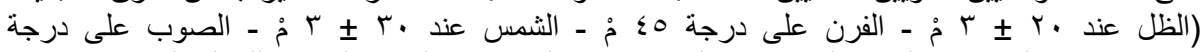

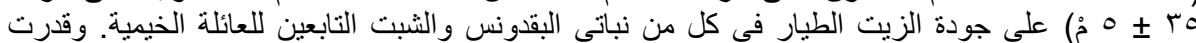
الصفات الطيبعية والكيماوية للزيت الطيار فى النباتات الطازجة. وقد أظهرت النتائج أن:

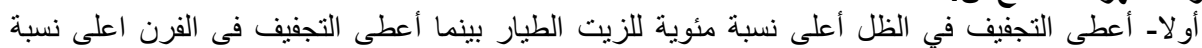

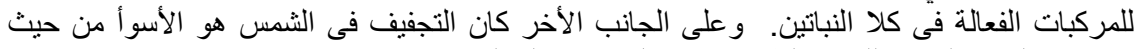

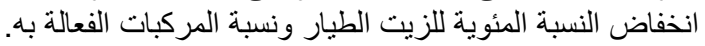

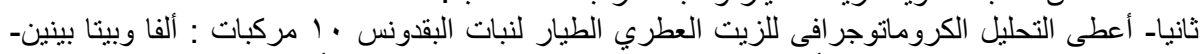

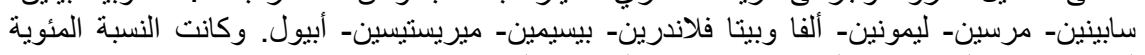

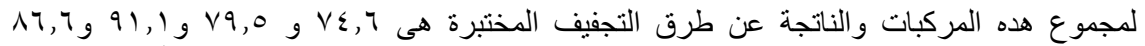

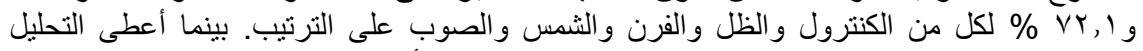

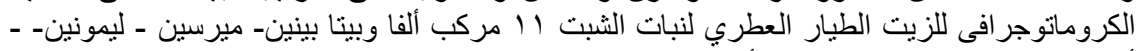

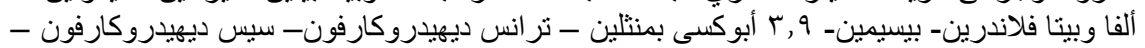

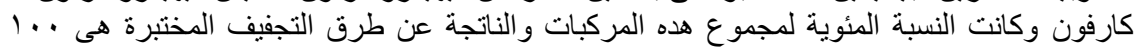

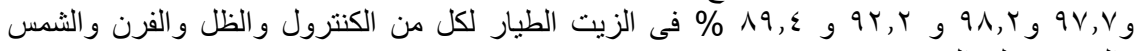
و الصوب على الترتيب.

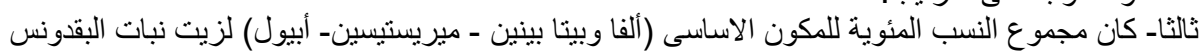

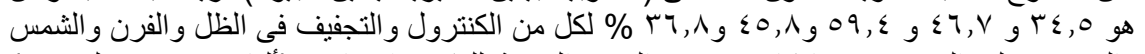

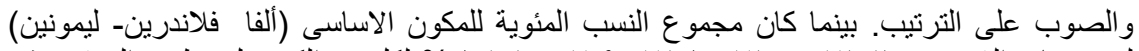

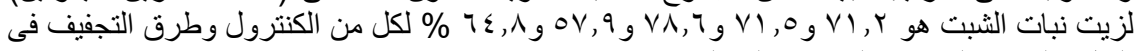

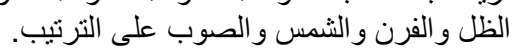

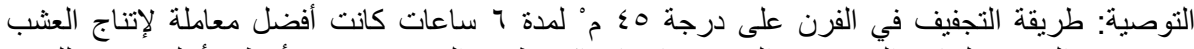

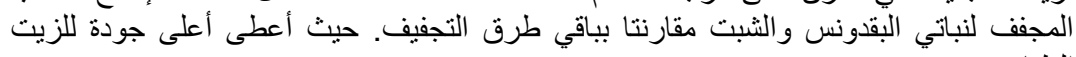
الطيار. قام بتحكيم البحث

كلية الزراعة - جامعة المنصورة

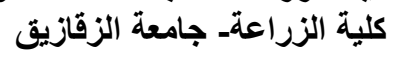

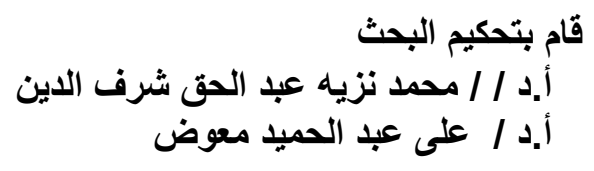

